\title{
Philosophical Foundations of the Dialogue between Science and Theology
}

\author{
Alexei V. Nesteruk* \\ University of Portsmouth \\ Lion Gate Building, Portsmouth, PO1 3HF, UK
}

Received 30.10.2017, received in revised form 29.01.2018, accepted 08.02.2018

\begin{abstract}
The paper discusses the philosophical difficulties in conducting the dialogue between science and theology. It is argued that theology deals with the event-like phenomena which cannot be presented in phenomenality of objects (what happens in science). Correspondingly, in order to incorporate the givens of theology (the "data" of religious experience) into a philosophical framework one needs to extend philosophy beyond its metaphysical and transcendental setting. This extension inevitably leads to the recognition of the fact that the foundation of both science and theology originates in human beings, having an ambiguous position in the universe which cannot be explicated on metaphysical grounds. The phenomenon of man remains inexplicable to man himself thus creating an ultimate reference point of the contingent facticity of both science and theology. The so called dialogue between science and theology demonstrates that the difference in hermeneutics of representation of the world in the phenomenality of objects and the inaugural events of human life and religious experience pertains to the basic characteristic of the human condition and that the intended overcoming of this difference under the disguise of the "dialogue" represents, in fact, an existentially untenable enterprise. Discussions on the differences in experience of the world and experience of God are profoundly timely for further articulation of the sense of the human condition, but not for its change.
\end{abstract}

Keywords: anthropology, communion, events, experience, hermeneutics, humanity, life, phenomenality, philosophy, science, theology.

DOI: 10.17516/1997-1370-0222.

Research area: philosophy.

\section{Introduction}

One observes a particular and characteristic feature pertaining to varieties of discussions on relation between science and religion which have taken place during the last thirty years: no visible progress and no change in their content. For many years conferences and published papers either consider scientific and educational ideas in the perspective of the historical Christianity or, alternatively, theological truths are adjusted to the standards of new forms of scientific thought. The main result of such discussions is that scientists continue their research as if the "dialogue" between science and theology did not exist at all, whereas theologians, being conscious of their limited capacity in the advancement of theology in view of modern scientifically based secularisation, sometimes defend their convictions

(c) Siberian Federal University. All rights reserved

* Corresponding author E-mail address: alexei.nesteruk@port.ac.uk 
in a narrowly historical and linguistic fashion effectively being forced into such a dialogue by an implicitly atheistic stance of its opponents. Sometimes the "dialogue" resembles not an attempt of reconciliation of science and theology, but a more articulate and precise demarcation between two types of experience, where the scientific component becomes a criterion of this demarcation. In other words, the "dialogue" transforms into a more detailed description of the difficulties of conducting of such a "dialogue" in general. The language employed in all discussions by theologians and scientists sometimes seems to be manifestly different, appealing implicitly to some premises which either cannot be linked to each other or have a common ground. What is the reason for that? From our point of view it must be sought in the lack of philosophical clarification of the very possibility of that which is called the "dialogue" or "mediation" between science and theology, or science and religious experience in general. In this article we explicate the difference between scientific and religious experience in philosophical terms by demonstrating that this difference pertains to the basic characteristic of the human condition and that the intended overcoming of this difference under the disguise of the "dialogue" represents, in fact, an existentially untenable enterprise. Discussions on the differences in experience of the world and experience of God are profoundly timely for further articulation of the sense of the human condition, but not for its change.

At the very inception point of the problem of science and religion, or the dialogue (mediation) between science and theology, the very possibility of relation of the scientifically given (data) and that which can be qualified as the given in experience of the Divine, is implicitly assumed.

Usually such a possibility finds its foundation in a mundane approach to the problem linked to the natural desire to establish a hierarchy of sensible images and intellectual representations of reality in a single consciousness without making delicate distinctions in the means of access to these givens and the degree of their rationality, that is in the modi of their phenomenality. One must take into account that such a philosophical insensitivity to various modi of representation of experience can lead to a reaction when the very possibility of comparison or mediation between scientific ideas and theological representations will be rejected as having no sense because the comparison is applied to the fundamentally "non-uniform things" thus having only an abstract character, comparable with the exercise of imagination and having no existential meaning. Such a reaction could be exercised by sceptically oriented scientists, as well as by sincerely believing Christians. However, the stance on mediation, as well as that one, which rejects its possibility, both contain a hidden philosophical premise, whose content is not spelled out, but implicitly predetermines the result of comparison of theology and science. All those, who deny the legitimacy of religious experience and its comparison with science implicitly justify their position by adopting a certain ontological commitment with respect to being of the world and being of God which, as such remains unclarified. In contradistinction to them, all those who employ the arguments based in religious experience, remain unable to express their position by using philosophical language that neutralises the objection of "atheists". However both approaches, either the first one that denies the importance of theology, or the second one, alternative to this, and diminishing the necessity of taking into account rational arguments from the positive sciences in order to strengthen the properly religious conviction, are both weak from the philosophical point of view, that is from the point of view of the rational representation of the holistic structure of the living experience 
of humanity manifesting itself through the difference between science and theology.

In order to clarify the latter point one can consider the situation when the fervent apologists of faith pose the question of the following kind: why one must take into account physical ideas whilst studying and developing theology? Theology deals with the specifically human way of existence, mystical, experience, liturgical life and Church, an ideal of salvation etc. and is not reduced simply to a mythology of the world? To what extent a Christian must be acquainted with the scope of knowledge of the physical world in order to be deified? One can employ a simple empirical response to this question by pointing out that the very possibility of theology (as experience of the Divine (independently of how the givens of this experience are treated)), that is the reality of its own existence and existence of its representations is determined by the possibility of existence of the incarnate carries of this theology (that is human persons). In other words, in order to theologise one must have necessary physical and biological conditions for existence of theologians, the conditions which, as it is not difficult to understand, are ultimately rooted in cosmic conditions. Cosmology and earthly physics (together with biology) explicate these necessary conditions. From here one infers a simple conclusion that any theological proposition (in thought or speech), expressing experience of the Divine contains explicitly a truth about the world as such, that world where this experience takes place. It is not difficult to see that the argument employed by us is ontological in the sense that it appeals to physical matter as the ground of existence which justifies the contingent facticity of theology.

If now sceptically motivated scientists reverse the previous question and ask as to "Why one needs theology for physics?", the response will be the following. Physics, in its cosmic dimension, argues about the factual state of affairs in the universe without clarifying the sense of its contingent facticity, that is, without clarifying the sense of the sufficient conditions responsible not only for the outcomes of the physical laws in order to have a given display of the universe, but also for the very possibility of knowledge and explication of the universe by human persons. Physics operates without giving an account as to how and why the study of the world (from microparticles to cosmological scales) forms a gift to a physically limited humanity. Theology, although it does not explain this fact, at least interprets it by pointing out that it is only human beings have the rational capacity of transcending the physically finite, that is to go beyond their own bodies and immediate life-world by integrating in their finite consciousness the representation of the infinite and intransient. Consciousness and reason form such characteristics of the human condition in the universe that cannot be explained by reducing them to the physical (ontological) and whose elucidation and interpretation is possible only through the appeal to theological anthropology of the Divine image. This leads the argument for justification of theology beyond the world order and its ontology. Correspondingly, any cosmological vision of the world is implicitly imbued with theology, for it is based in a Divine gift of faith in reality of good creation of Good God, as well as in the gift of the possibility of thought and linguistic articulation of the universe as a thanksgiving offering of creation back to the Creator. The ontological argument for the very possibility of theology, employed by us whilst responding to the first question, is typical for any metaphysical justification based on the principle of causality (consciousness is epiphenomenon of the physical), or on the principle of the sufficient reason. One also needs to add the principle of knowability, that is a transcendental stance on finitude of knowledge (knowledge is limited by 
the conditions of corporeality (embodiment)) and the limits of access to infinity.

As to the response to the second, opposite question that existence of consciousness and its rationality is linked to the idea of God, it does not have the same philosophical clarity as it was in the first case. Namely, the appeal to the idea of God implies a propensity to faith which is not evident and convincing in the context of the transcendental stance on the possibility of knowledge. Here one introduces a theological argument which appeals to those givens of experience that are radically different in comparison with what is given in physics and cosmology. These givens of experience are related to the fact of the human existence understood not only at the physical (natural) level, but also as personal (hypostatic) consciousness. Here one implicitly appeals to such a modus of experience which is not rooted in the natural (ontological), but is related to a different modus of the given. It is the difference in the modus of the given, revealed by us in the course of the argument in favour of impossibility of avoiding cosmological insights in theology on the one hand, and in the implicit appeal to the theology of communion (for the possibility of cosmology), where the very fact of life turns out to be an inaugural revelation, on the other hand, that points towards an asymmetric relation between the metaphysical interpretation of the possibility of theology as an empirical and discursive representation of the living experience (based in the power of scientific arguments) and properly "theological justification" of science on the basis of the immediate givens of the human existence, whose metaphysical instability (as passivity and affectivity by nature, time, flesh etc.) and transcendence (as an attempt to unfold life's hidden foundation) turns out to be a phenomenological pointer to the realm of the Word and Spirit, lying in the foundation of life as such. The "dialogue" between science and theology thus becomes a discourse of clarification and explication of the difference in the ways of appearance and access to the givens in science and theology in one and the same human subject.

\section{How to make philosophically \\ the distinction in the modi of the given in the natural sciences and theology and what are the limits of such a distinction?}

The philosophical criterion of the difference in the modi of the given in the natural sciences and theology can be formulated in the following way. Any scientific research and any theory assume the acceptance (whether explicitly or unconsciously) of the system of metaphysics (metaphysica generalis), that is ontology (ontologia), so that such a research implies that it studies an object which must exist beforehand, that is to be an existent (ens). This requirement holds for every specialised metaphysics, that is for specific sciences, as well as for the representation of God in philosophical theology (theologia rationalis) (which is distinct from theology understood as experience of communion with God, that is from theology of revelation). On the one hand, metaphysics deals with the issue of existence of God (and here the whole drama of possible proofs of this is unfolded), whereas on the other hand, there is a question about essence of God. One notes that the requirement for the metaphysical certainty can also be applied to theology understood as historical or linguistic tradition (whose foundation is in communion). For example, there can be a metaphysical demand for the existence of Biblical events in order the latter to be justified from the point of view of the historical sciences. Similarly, the corresponding fragments of the sacred texts must receive their interpretation and thus objectivisation through their qualification by the rules of linguistics and the sciences of the languages. However, when we 
use term theology in a proper sense, we depart from the metaphysically defined definition of its subject as if it is positioned in a sort of underlying substance. One means the theology as communion with God, so that in this case the most burning question is how to establish the difference on the metaphysical basis between philosophical theology and theology of communion. The provisional response to this question can be formulated like this: the difference consists in the extent of appearance (phenomenality or presence, display) of beings (existents) (that is, their "positivity") concerned, and of the ways of ontic verifications in philosophical theology and theology of communion. Here one can recall Heidegger who in his famous article Phänomenologie und Theologie of 1928 considered theology (including also a nonphilosophical theology) as "wholly autonomous ontic science" because of its "positivity" and then, as a consequence, its dependence on the analytics of Dasein, considered as a fundamental ontology. This, according to Heidegger, confirms the primacy of ontology with respect to theology, as well as with respect to all special sciences. ${ }^{2}$ Generalising, one can say that the difference between ontic sciences (majority of the human sciences) and ontological sciences (for example, physics, whose ontology is based in physical substance and rubrics of space and time which constitute the precondition for any articulations of reality) presupposes the difference in ontology behind these sciences, and the hierarchy of those sciences follows from the "hierarchy" of ontologies (assuming that one can define one ontology as more fundamental than another). Physics is modest in claiming that its ontology is associated with the corporeal function of man. Then there is a question as to whether exists such a philosophical system that could assert the universal ontology, which can be placed in the foundation of both the sciences and theology, that ontology which could subordinate either theology of communion or philosophical theology? One can rephrase this question in a paradoxical way: since ontology (and its primacy with respect to the ontic sciences) has sense in a metaphysical system, what can be left of such an ontology at the era of the "end of metaphysics". One can refer to Heidegger who stopped using the term "metaphysics" in order to «to think Being without beings», that is to "think Being without regard to metaphysics" (Heidegger, 1972: 24), when he refused being in favour of event (Ereignis) ("Being vanishes in event" (Heidegger, 1972: 22 (translation corrected)), "Being would be a species of event, and not the other way around" (Heidegger, 1972: 21 (translation corrected)) ${ }^{3}$. Essentially he says that one cannot treat theology of revelation (as events of communion with God) in the context of the ontic status of these events as if they would be only specific historical events. If previously the notion of event was shadowed by the background of metaphysics, so that an event needed original ontology in order to take place (for example, in physics, there must be space-time for events to happen, and these events form the structure of the former), the modern development of phenomenology leads event beyond the existent, beyond being. One cannot assign the modus of the already conceived existence to an event. Event can be described as the consummation of that, whose essence did not give the possibility of its foreseeing as if one could foresee the inconceivable impossible from the perspective of the conceivable possible (that is from within metaphysics with its principle of causality $)^{4}$. Finally, if even the ontology of Dasein is doubted as a pretender for the universal ontology, what kind of an alternative could be proposed as the foundation of theology? If the very development of philosophy and the mutable character of the fundamental physical structures in the natural sciences places man 
and his thought into the "non-metaphysical" (or post-metaphysical) situation, can this thought use an ontological criterion in order to carry out the distinction between science and its philosophical appropriation on the one hand, and theology of communion on the other? The implied answer is "no", so that philosophy as such must extend towards appropriating phenomena with the eventlike structure which cannot be appropriated within the frame of metaphysics.

Here one approaches new possibilities of a philosophical reflection upon that which is metaphysically impossible. The essence of event is that it predetermines and redefines all possibilities of existents in their being and it is in this sense that it can be assigned an ontological status. One follows from here that the more a phenomenon takes place in its phenomenality as an event, the more it doubts its metaphysical modus of being, for its sheer possibility follows from its effective metaphysically understood impossibility. Theology of communion confirms this, for it deals with the events whose impossibility witnesses to what is expressed in the Bible in words "nothing is impossible for God" (Gen. 18:14; Lk. 1:37). One implies here the events such as creation of the world out of nothing, the Incarnation of the Word-Logos of God in flesh, the Resurrection etc. These events resist the possibility of their non-contradictory comprehension (in a metaphysical sense) preventing the formulation of their identity status (on the ground of the principle of contradiction), that is, in different words, they challenge ontology and its definition of being.

The "essence" of events of creation of the world, the Incarnation and Resurrection is exactly that that they do not reduce to that which follows ontological law patterns. These events make possible that which is not presented on the ontological level, which is not identical to itself and whose existence contradicts its essence. One can express the same by saying that "essence" of these events contradicts to itself, for referring to a biblical case when God "calls into being things that are not" (that is calls into being non-existent as existent, as if non-existent would exist) (Rom. 4:17). It is in this latter sense that such events par excellence as creation, incarnation and resurrection, one can say, acquire a "metaontological status" because they (events and all existents involved in them) contradict to the laws implied by ontology.

The world of things (the universe) receives a new interpretation in accordance with that which grants being, so that the world acquires being in that moment (event) that exceeds the measure of any possible definition of the existent. Being created the existent receives its being from God, not resulting from the laws, outlined by thought in rubrics of ontology. In light of such a reversal, when ontology (as the possible) becomes subordinated to events (as sheer impossibility), the relation between theology of communion and metaphysics experiences an inversion, so that the latter becomes to be determined by the former. By this, one neutralizes an ontological criterion in establishing a relation between philosophy, philosophy of science and theology, by introduction "into play" another criterion, dealing with the difference between the possible and impossible, that is the difference between that which can be a matter of experience and that which cannot. The implied criterion is based on the assumption that one can apriori state the limits of rationality, that is to formulate conditions for possibility and impossibility of experience. It is because of the Copernican turn by Kant that the finite reason defines the infinite, claiming impossible its knowledge on the grounds of the limited cognitive capabilities. The finitude and limitedness of reason thus assume the functioning of the principle of transcendental apriori. If the finite structure of consciousness 
does not have a transcendental status, it cannot legitimately make distinction between what is possible and what is impossible. It follows from here that the difference between scientific philosophy and philosophy in general, on the one hand, and theology, on the other, on the basis of distinction between the possible and impossible, can be articulated in principle only if philosophy and corresponding philosophy of science function as being part of the transcendental discourse, that is under the assumption of the transcendental subject who exercises such an articulation. This transcendental stance finds its justification in that trend in philosophy of science which shows that the formation of views on the structure of physical reality is intimately linked to the conditions of access to this reality through experiment and mathematical expressibility ${ }^{5}$. Since the transcendental stance is present in the fabric of phenomenology, it is the latter that can be chosen as a methodology for making an enquiry into the theoretical legitimacy of theology. Phenomenology, being an efficient method (among other philosophical trends) of maintaining the difference between philosophy (and methodology of science) and theology is capable of supporting this status unless the inherent transcendentalism is not itself subjected to a historical and epistemological correction.

Thus one cannot conduct a reasonable demarcation in the subject matter of science and theology without an appeal either to ontology or transcendental interpretation of possibility of experience, that is, of the subject of knowledge. All other possible ways of such a demarcation turn out to be arbitrary and transient, not having any existential foundation. Since the era of the "end of metaphysics" doubts the possibility of the universal metaphysics for demarcation of philosophy and theology, one is left with a question as to whether the transcendental principle remains valid in order to be placed in the foundation of such a demarcation. If the latter is impossible for events of communion and as well as for some phenomena in modern natural sciences, anthropology and the human sciences, then the transcendental argument for delimiting and making a distinction between science, philosophy and theology turns out to be impotent and philosophy is challenged by the necessity of developing new methods for dealing with situations when human knowledge and experience encounter the infinite and fundamentally impossible.

Coming back to the purpose of our discussion of establishing the difference in the modus of the given in the natural sciences and theology (answering as well in passim as to why one needs physics for theology) we proposed a metaphysical and transcendental argument that all givens of consciousness and experience of the Divine depend on the difference in the underlying ontology in the sciences (physical substance and biological formations) versus ontology of events, that is modi of phenomenality following from structures of subjectivity, adapted to the material environment. By so doing we have implicitly established delimiters between science and theology pointing out that in spite of the explicitly ontic features of theological knowledge, as distinct from the ontologically rooted natural sciences, the very ontic needs to have an ontological basis (as a corporeal basis of a subject), whereas the ontological condition must be elucidated through the structural path of its constitution by subjectivity (that cannot be accounted on the level of ontology). Thus the strict demarcation between science and theology on the basis of the opposition between ontic and ontological can hardy be achieved contributing to the argument that a naïve positing of experience of the Divine outside the material conditions of the possibility of this expression represents de facto faith without reason, whose existential and 
soteriological meaning remains obscure, whereas any physical reductionism in the constitution of humanity also fails without, de facto, an appeal to theology of human creation. However, the use of metaphysical and transcendental arguments in justification of theology encounters a difficulty consisting in the fact that the very dialogue between science and theology does not represent any metaphysical or transcendental necessity but has features of events of life pertaining to human reason and free will that cannot be as such deduced on the grounds of causality to any ontology. Here one deals with such event-like phenomena that relate to life's self-affectivity, so that their interpretation demands new philosophy that deals first of all with the phenomenon of man understood as an event of life, the phenomenon that has a "meta-ontological" status, blessing and justifying de facto the possibility of the philosophical as well as scientific knowledge of the world.

\section{How to make a theological distinction in the modi of the given in the natural sciences and theology?}

If in the previous section we have established that theology, unlike philosophy and the sciences, deals with event-like phenomena denying ontology to the impossible and thus exceeding the capacity of transcendental delimiters, then the question arises: how is theology possible at all? To discuss this issue one inevitably enters the realms of theological anthropology since the answer to this question ultimately refers to the reality of the human. The Patristic model differs from the modern, widely accepted understanding of the human person as a being endowed with a reasoning brain, consciousness, will, and emotions. The early Fathers considered the human person not only in the light of the dualism between body and discursive reason (dianoia, or intellect in its contemporary sense, the mind).
They made a subtle distinction between dianoia and nous, in which the latter stands for the faculty of apprehending truth, which is superior to discursive reason. Nous can be broadly explained in modern language as spiritual insight or as spiritual intellect where logic cannot be used.

Dianoia (reason, mind) functions as the discursive, conceptualizing, logical faculty in man; it employs such particular cognitive operations as dissection, analysis, measurement, and the use of mathematics. The function of dianoia is to collect information about phenomena in the phenomenality of objects. The limits of dianoia are outlined by its ability to draw conclusions (by syllogistic deduction) and to formulate concepts (by induction). Dianoia is similar to object-orientated thinking, which by definition aims to obtain knowledge of an object, posed in thought as an external object, by means of the logical formulas "A is B" or "A is not B."

It has been clear, since the early Fathers, that dianoia can be applied only to things that allow rational thinking, that is, to things of the created world. Maximus the Confessor comments thus: "Created beings are termed intelligible [that is, they can be grasped by the reason (dianoia)] because each of them has an origin that can be known rationally [that is, discursively]. But God cannot be termed intelligible, while from our apprehension of intelligible beings we can do no more than believe that He exists. ${ }^{.0}$ Rational thinking (that is, dianoia) cannot be used in theologia, in the immediate vision and experience of God. Knowledge based on the dianoia does not imply any direct apprehension or perception of the inner essences or principles of created beings, still less of divine truth itself. The apprehension in the latter sense is made possible only by nous and is beyond the scope of reason.

In contradistinction to dianoia, the nous works by direct apprehension. Its subject matter is not simply outside itself. It does not reason from 
premises to conclusions by strict logical steps; rather, it apprehends the truth through a kind of inner vision through which he knows God or the inner essences or principles of created things by means of direct apprehension or spiritual perception. According to Maximus the Confessor: "The intellect [nous] is the organ of wisdom, the intelligence that of spiritual knowledge." "It possesses the capacity for a union that transcends its nature and that unites it with what is beyond its natural scope. It is through this union that divine realities are apprehended, not by means of our own natural capacities, but by virtue of the fact that we entirely transcend ourselves and belong entirely to God."»

This aspect of transcendence exercised by nous closely resembles that which could be simply called faith. One can conjecture that nous provides conditions for faith to be intentional: one who wants to find God through reason can do it, theoretically speaking, by developing one's nous. At the same time, it is clear that the exercise of rational faculties in order to develop nous requires one, in a sense, to deny the rational faculties that one starts with. Faith sometimes is juxtaposed with knowledge. In our context, this juxtaposition means one of nous with dianoia.

The nous thus provides a foundation for reason to infer from the created things to the existence of God, that is to experience the foundation of all things in their otherness (that they are created). This inference constitutes faith in existence of God and is granted to a believer by God himself: "Faith is true knowledge, the principles of which are beyond rational demonstration; for faith makes real for us things beyond intellect [mind] and reason (cf. Heb 11:1)." "9 Faith, whose organ is nous, allows us to transcend general conditions of knowledge imposed by mind and reason with respect to things of this age and "see" not only the intelligible realities but also the underlying principles of existence of all things leading to God.
So how is theologia possible? The answer so far is that theologia as experience of God is possible because humans have the faculty of nous, which allows them in principle to have experience of God, that is, to be in communion with God. It is clear for any careful reader that the logic of our argument is based, in fact, on the acceptance of the Christian Patristic model of human being, being a part of Orthodox theology. It is important also to realize that the affirmation that nous makes theologia possible assumes, in fact, not only that this faculty is present in human composite but also that nous is related to the essence of the human person, to that individual, distinct link that a person has with God and which makes one person different from another. This clearly indicates that there is something in nous that transcends the natural aspects of the human person (the body and soul). In Patristic thought, body and soul constituted the natural composition, which is held in human hypostasis. St. Maximus compares human composite with Christ. The unity of body and soul in Christ is purely hypostatic (that is, non-natural), whereas in humans the same unity is not only hypostatic but also natural..$^{10}$ It is exactly this unity that, according to Maximus the Confessor, constitutes a person. Realizing one's potential toward full existence makes a challenge for nous; if humans succeed in this - that is, if they manage to establish ultimate personhood their nous will fit for theologia, for the mystical contemplation of God to the extent that is possible for humans. ${ }^{11}$

Thus philosophy as a modus of consciousness related to the faculty of dianoia can deal only with things of nature. God exceeds its capacity and thus is inaccessible to dianoia. However, theologians (in contradistinction to philosophers) know about the defect of nature and of the natural in man (related to the Fall) and recognise the necessity of transfiguration of nature, that is its perfection in the image of the supernatural. In 
other words, if philosophy and science interpret beings only in the measure they see in them the natural, for theology remains that which either does not possess nature at all or exceeds the limits of the latter. Here the problem arises: how the natural man can achieve the Divine grace in the vision of God, that is transcend its own natural faculties, that is to employ that which is present in him latently, that is nous. The problem is whether the natural formation can develop a desire to access something which cannot be achieved in the limits of this nature. The answer is "yes", man can develop such a desire, first of all when he questions his own essence. Indeed, one cannot know his essence in a metaphysical sense for, according to theological definitions, man must remain undefinable as a carrier in its essence and hypostasis of the image of the undefinable God $^{12}$ (undefinablity of the essence of God deprives man of the essence which can be defined). It is exactly this that inspires man for the acquisition of grace as the supernatural Good in order to try to understand the sense of himself. Thus dianoia (dealing with knowable aspects of man's physical existence) and nous (as having an insight on the insufficiency of dianoia's knowledge of man) cannot be separated in a real man, both of them function in parallel although the advance of one with respect to another depends on a particular personality. It follows from this observation that the strict separation of the cognitive faculties onto a philosophical and theological modi cannot be applied to man without distorting the fundamental feature of the human condition, namely the unknowability of man by himself.

The difference between the natural (the realm of dianoia) and super- or trans-natural (the realm of nous) which one could, by the way of a historical analogy, apply for the demarcation of science, philosophy and theology, fails irrevocably in the case of a human being that by the fact of its existence, represents a synthesis of the natural and supernatural. The natural dimension in man, in corporeal setting in being, cannot be detached from his consciousness that cannot be reduced to the natural on the basis of the laws of causality (which are necessary for the human condition, but not sufficient), that consciousness which as a distinctive feature of his definition as made in the image of God, cannot be explained by man himself. It is man (as a generalised notion of humanity) that forms the major concern and subject matter of theology where the natural and supernatural cannot be clearly separated and detached from each other.

The impossibility of knowing the essence of man shows that a possible ontological response (referring to the substance of the world of which man is made) to the question as to why theology needs cosmology, is not sufficient, for the human phenomenon exceeds the boundaries of the scientific and philosophical and needs a supernatural (theological) elucidation. Correspondingly the contingent facticity of physics and cosmology, as accounting for the foundation of the natural condition of man, cannot receive explanation from themselves in the same manner as the essential aspects of the human condition cannot account for themselves. Since the very fact of the human existence as exceeding its own naturalness and possessing its own hypostasis cannot be accounted through cosmological theories, this fact remains beyond the circle of causality pertaining to the world's ontology, that is man deals with himself as an event saturated with the intuition of communion with the source of life. Thus cosmology needs theology to "justify" the very possibility of cosmology as a modus of the human existence. However, here, the implied argument is not ontological but appealing to the event-like phenomenon of a particular human life, the phenomenon which saturates intuition to such an extent, that it cannot be accounted on the grounds of causality and within the 
limits of the transcendental cognitive faculties. This event-like phenomenon has an extensive content, starting from the actual event of birth and finishing by particularities of life unfolding into the future, that which has been given as a gift of life at the moment of birth. It is not difficult to see that the modus of the given in the phenomenon of man as a centre of disclosure and manifestation of the relations between the world and God turns our to be fundamentally different in comparison with science and philosophy: the essence and structure of the outer reality (as the givens in the representation of consciousness) receives its "meta-ontological" justification in inaugural (opening) events such as an event of human life, humankind-event, an event of creation (birth) of $\operatorname{man}^{13}$ whose phenomenality is not that of objects studied by the sciences. Cosmology needs theology in order to realise that the approach to seeing the universe as a physical object, typical for cosmology, is based in an event of life of a hypostatic human being, the event which cannot be subjected to a purely ontological description, but receiving its interpretation from theology as that understanding where man was brought into existence by the will of the invisible origin. In this case cosmology as a consequence of the event of life receives its justification from theology of communion dealing with the inaugural (opening) events, first of all with the event of birth. The image of the world is built in the conditions of the presence of the divine image in man in these inaugural events. However this image remains limited and unaccomplished since the sense of divine image in man remains hidden and unknowable for man himself. This happens, theologically speaking, because the divine image in man remains only an image and not likeness, lost after the Fall. The very knowledge of the world as an adaptation and arrangement of man's place in creation forms a constitutive element of that which named the Fall. ${ }^{14}$
Thus the undefinability of man and his unknowability by himself as having a theological interpretation forms the precondition for the actual limited knowability of the world (this is not a transcendental condition related to the embodied human faculties). This implies that cosmology follows the same apophatic pattern of explanation which is typical for the theological anthropology of the divine image. ${ }^{15}$ The difference in the status of phenomenality of "things" in cosmology and theology amounts first of all to the limited scope of cosmology and unknowability of the universe understood as creation (and not as a fragment of the physically observed cosmos), for the sphere of its phenomenality (linked to the astronomical objects and inferred theoretical constructs) does not take into account the eventlike essence of man: knowledge of the world unfolds as if consciousness of this world exist without any recourse to the event of coming into existence of corporeal persons. By neglecting the foundation of knowledge in events of the human existence cosmology deprives itself of realising that the structure of the given in cosmology is ultimately determined by the present facticity of consciousness having sense of revelation for man himself, theologically treated as the revelation of God. In such a vision the fact of life, as well as knowledge in philosophy and science (as modi operandi of life) are seen as outcomes of the Revelation understood as the given in the eventlike phenomenality, incorporating all specific forms of philosophical and scientific knowledge (although the very givens of Revelation are not accessible in a non-mediated form, that is without a special procedure of their appropriation).

One may focus a bit on the latter point by making a historical reference to what was implied in mediation between the givens of Revelation and knowledge, theology and philosophy. Theology proposed some special epistemological conditions of justification and 
appropriation of the phenomena of communion by extending rationality towards such existential notions as faith and love. Clement of Alexandria, for example, declares that knowledge is possible only because of faith and that faith is a condition for knowledge of any kind. Conversely, knowledge helps make affirmations of faith demonstrable and thus, according to Clement, more scientific. The faith that is true knowledge of revelation becomes a more scientific faith when supported by philosophy, and in this way it becomes gnosis. ${ }^{16}$ Clement emphasizes that to enable faith to overcome the lack of necessity and rigor of mere opinion, one must appeal to the methods used in the sciences. Since knowledge is based on demonstration emerging from the first principles that cannot themselves be demonstrated, knowledge itself cannot be demonstrated. This in turn implies that the very possibility of knowledge requires the acceptance of first principles, that is faith in them (to use scientific methods for the study of the world one should believe in the possibility of these methods, that is to believe in man as an empirical and unknowable fact of the Divine Revelation). In this way, knowledge depends on something that is not knowledge; this is faith: "For knowledge is a state of mind that results from demonstration; but faith is a grace which from what is indemonstrable conducts to what is universal and simple, something that is neither with matter, nor matter, nor under matter". ${ }^{17}$ It is faith, therefore, that allows one to formulate the first principles in a proper way and to perceive things that are not seen in the course of demonstrable knowledge. Demonstration then follows after faith, but not the other way around. Then a demonstration based on reasoned knowledge produces faith in those who wish to learn of God (and man) by examining the Scriptures. Clement calls this faith that is supported by philosophical methods (that is inclusion of events of communion into the philosophical sphere) a considered faith (that is, a gnosis), and according to Clement, it forms the subject matter of theology. If existential faith is in the foundation of any knowledge, this faith concerns man as having access to knowledge of God and the world. Faith (as belief distinct from certainty of knowledge) becomes in this case an epistemological equivalent of the undefinability and unknowability of man by himself that, being empirical facts, require their acceptance as a particular but inaugural Revelation of God to man.

Another example of how the givens of Revelation are appropriated in knowledge can be found in St. Augustine who promoted a view that from the very beginning Christianity doubted any comparison with ancient religions (theologia civilis and theologia fabulosa), making possible its encounter only with theologia naturalis, that makes an effort of studying the Divine from the movement of the heavenly bodies. Augustine insists on the only adequate use of the term theologia for Christian faith as true knowledge of the Divine. Since one speaks of truth “... comparison must be made with philosophy (cum philosophis est habenda conlatio)". Thus philosophy must deal with faith, for, as Augustine concludes "a true philosopher is the lover God (verus philosophus est amator Dei)."18 Love for God that is laid by Augustine in the foundation of true theology presupposes communion as an empirical source of any proposition and rational thinking about God. Philosophy as a rational "response" to Revelation must acquire a shape which is adjusted to the appropriation of those phenomena from the realm of revelation which a-priori do not fit the schemes of metaphysica generalis and transcendental epistemology.

In both cases, in the Greek East and Latin West, the sense of theology implied the acceptance of principles of the immediacy of communion, whose givenness in experiential 
and empirical knowledge of God was not immediately evident and verified, universally inaccessible to all, and following from the mysterious aposteriori remaining real and true in its given facticity. Speaking of communion one implies first of all events of relationship between God and the world, creation of the world, the Incarnation of God in flesh, Resurrection and other personal events of saints and ascetics, all given in the unforeseeable experience in the sense absolutely impossible from the point of view of their scientific-like explanation in the limits of metaphysics as if one could determine beforehand the anticipating horizon for these events. In the same vein one cannot define apriori that transcendental subject whose cognitive faculties would correspond to the possibility of placing the events of communion (as unrepeatable, devoid of their ontological definition and propensity of their objective representation) in the limits of experience. Communion allows one to open a possibility of a new type of understanding of inaccessible and metaphysically impossible phenomena by extending the limits of rationality as such. If human rationality is understood as a natural reaction of the understanding to form a response to the events of communion, it is the task of philosophy to comprehend how the new givens of these events do fit into the framework of rationality. It is the main challenge to philosophy from theology of communion and, correspondingly, to the dialogue of theology with the rationalism of scientific understanding. Namely, philosophy must extend by appropriating, through the non-metaphysical philosophising, theological experience and, as a result, to undertake a philosophical demarcation between scientific experience and experience of communion. How does rationality succeed in appropriating experience of communion and how do its paths differ from rationality's modus operandi in the sciences?
In order to recognise that theology as such as well as its relationship with science lead necessarily to taking into account the events of communion as new, but truly givens which require an epistemological qualification, one first needs to recognise the fact of their existence, their reality and unavoidable origin in the event of life in general. For a naturalistically oriented scientist any link between experience of living (with its intrinsic codification of the event of creation of the whole world (in which the possibility of the corporeal existence is granted)), the event of the Incarnation of the Word of God (in order knowledge of the universe to be possible in the archetype of the Divine image), the very moral teaching of Christ (for the civilisation to escape chaos and destruction), the Resurrection (that gives hope to man and determines the goals of knowledge), all these events involving a new type of givenness do not possess any certainty and validity. From the point of view of such a scientist the acceptance of the abovementioned events (and similar to them) in the scope of epistemologically extended rationality implies an element of faith (that is an opinion or judgement), so that the incorporation such events in the scope of rationality has sense only for believers. However, in this distinction between faith and non-faith (believing or not believing, between doxa and episteme) there is an element of metaphysical thinking present implying the distinction between faith and knowledge on the ontological level and within the transcendental setting. But, as we have already stated, these criteria of distinction cannot be applied to man himself, who is the source and origin of such a distinction, so that by denying or abandoning an aspect of faith in respect to knowledge of man, one means the intentional denial of his unknowability by himself, that is the distortion in representation of the sense of the human condition and thus the distortion of truth in general. It follows from here that the primary 
given of events of communion which requires a rational reaction and epistemological qualification is the givenness of man to himself, that is the mysteriousness of life as self-affectivity, as life from Life, that which is in the foundation of man's faith in reality of his own life.

Communion, unlike mundane wisdom, happens on the initiative of that who is beyond any metaphysical and transcendental conditionality of that wisdom in man. It is the transcendent (eventlike) character of communion that makes possible to maintain a clear-cut distinction between that which is disclosed in revelation and that which is constituted as an object of knowledge. By quoting a fragment from an Epistle to Hebrews 4:12, "The word of God is alive and active. It cuts more keenly that any two-edged sword, piercing so deeply that it divides soul and spirit, joints and marrow; it discriminates among the purpose and thoughts of the heart", one can make a conclusion that it is the Word of God (as the Logos, that is reason), that is capable to discriminate in knowledge that which belongs to man and that which originates in God, that is that which is revealed. One can object again by saying that this criterion implies faith and hence aims at believers, so that the distinction between human knowledge of the world and thinking of God implies that there is something given in communion that (depending of a particular person) is either accepted or not in face of the Word of God, that is reason (Logos), that is something enters or not in the realm of the experienced or thought. If that which is given in communion is accepted, then theology receives its justification from that these givens are included in the sphere of phenomena, in its rights the same as all other givens, but requiring a special epistemological justification within the extended rationality. If, alternatively, the givens of communion are not included in the sphere of phenomena, they remain inarticulate and metaphysically impossible.
As we have seen above faith was that condition of acceptance of the givens of communion into the sphere of phenomena, which could be appropriated on the grounds of rationality extended through this faith. Faith, being a condition for accepting the givens of communion, being one of the virtues, according to (Cor. 1:13) is inseparable from hope and love, where love is supreme and "remaining to the end." This is the reason why the acceptance of the givens of communion implies that that which is received and That Who gives is not just an "object" of contemplation, but first of all the "object" of love as love for truth. In communion love changes the modalities of knowledge, that is epistemological criteria of reception of the givens in communion as the manifestation of love to truth. According to Augustine love is the condition that what is being known is true: "the only way to truth is by love"19. In other words, truth is rooted in love as its epistemological condition, not because truth cannot be fully disclosed without love, but because it is love itself that is the ultimate and only foundation for the possibility of seeing and grasping truth. ${ }^{20}$ Pascal expressed differently a similar thought: “. .au lieu qu'en parlant de chose humaines on dit qu'il faut les connaître avant que de les aimer...., les saints au contraire dissent en parlant des choses divine qu'il faut les aimer pour les connaître, et qu'on n'entre dans la vérité que par la charité..." ("With respect to human things it is said that it is necessary to know them in order to love,... the saints, on the contrary, say, of divine things, that they must be loved in order to be known and that truth (vérité) is manifested only through love (charité)") (Pascal 2001: 8). Love, however is not that which is simply commensurable with experience of mundane reality. It demands one to overcome the sense of despair and futility of human existence, which was articulated by Pascal in his Pensées, and to acquire love to God: "Qu'il y a loin de la 
connasaince de Dieu à l'aimer" ("What a great distance between knowledge of God and love to him") (Pascal 1962: 161). It is only this love can guarantee an access to the "great reason", for it is love given to us in the revelation of the Word, that is the Logos, which reveals itself as logos, that is as rationality which makes it possible to approach the phenomena which are more close and more intrinsic to us, those which are experienced by the spirit-bearing human flesh and exceed the capacity of being grasped by discursive thinking. Here one means first of all knowing of human person by himself including the facticity of its all-encompassing consciousness manifesting life. Then one can speak of knowledge of the universe as a whole as creation being "coincident" with life and every person through an instantaneous intellectual synthesis. One can overcome the feeling of non-attunement with the universe, one's solitude in it and anxiety of non-sense of being, with the aid of that "great reason" which incorporates these mysteries into the scope of its givens whose reality and truth is guaranteed by love to life and its Creator. The "great reason" implies the mind of Christ-Logos, by whom and through whom the universe was created and for whom, after the Incarnation in flesh, the whole universe was intelligibly given in its fullness as an instant of the Divine love, and who remains the Lord of the worlds (Jn. 1:16).

Creation of the universe manifests the perfect love, that is the unconditional supremacy of love in relation to being: God created the universe out of his love and does not expect its recognition from the created, for God is above and beyond of that which he created. Knowledge of the universe as creation implies the hidden knowledge of Divine love and not only that which was created. Thus the contemplation and understanding of the universe as the event coincident with the event of life, that is perception of the universe as given at the moment of beginning of life, requires to follow the same unconditional love with respect to life as such that was in God creating the world out of nothing.

Christian love justifies the very possibility of true knowledge, for that who loves, that is, believes in God, everything is possible, including knowledge of truth. The loving human being has the same privilege which God has (Mark 10:27). Christian love makes possible the "impossible knowledge" of man by himself, although in a reduced form, as sensing of its own centrality in creation as the God-given ability to know oneself through knowledge of God. To know truly one should be known by God and for this one must love God (1 Cor. 8:3). To know oneself truly and to know the universe truly means to have knowledge not by one's own thought, but by the thought of Him, who discloses himself only to those who love him. Knowledge of the universe as self-knowledge in order to be true requires the acquisition, as its archetype, the "mind of God" through love to him. But this is not what is given to humanity in its natural propensity. To know through love and to know through God's "mind and eyes" requires one to exercise one's will. Christian love means the ability to approach things and to see in them the divine presence contrary to their compelling empirical evidence, that is to see that presence which can only be manifested to humanity as a carrier of free will and love. To know things through love and will means not their passive contemplation, but active participation in them, a sort of communion with them which allows one to get access to an otherwise inconceivable transcendence of other creatures and essences. Here love takes responsibility for that which is affirmed in philosophy and science because it Christologically reinstates the definition of philosophy, and hence the sciences, to their proper sense as "love of wisdom" or "love of truth" leading them beyond their metaphysical limitations and appealing to a new epistemological exploration of those phenomena 
that are possible contrary to their seeming metaphysical impossibility and exceeding the limits of their transcendental definitions. Without love, human reason is limited in interpreting the world, by transforming it into objects of possession and hence dealing only with their deficient phenomenality.

Christian love aspires for such a metanoia in the state of the human mind that the created world appears to it as it is contemplated through the "eyes" of the Logos through whom and by whom all is. It is because of this metanoia that in spite of scientific persuasions on insignificance of our place in the universe to the extent that one could detest life because of its absurdity and ontological homelessness, that love for the truth of life itself (as an entrance into the mysterious and extraordinary state of being alive) gives one the power of recognising in man a glimpse of truth of its origin from Life, that is not seen at the empirical level and is metaphysically inexpressible. One means Life that "was life, and that life was the light of mankind" that was in the Word that was in the beginning; and "the light shines in the darkness, and the darkness has never mastered it" (John 1: 1-5). Man in his present condition cannot "see" this light not because this light is "weak" and "dim" so that there is the lack of its phenomenality to man, but, on the contrary, because this light of life is given to man in an absolute excess by "overexposing", that is saturating intuition to such an extent that the source of life as its origin becomes invisible. Unknowability of man by himself originates in his presence in front of such an excess of life that blocks the possibility of any ultimate comprehension of man by himself in categories of understanding and by reason. Christian love is capable of leading man to the recognition and acceptance of the fact of the unconditional givenness of life as a gift originating in Life in the Word.
By analysing special epistemological conditions for justification of phenomena of communion (where the first one is the revelation of life to man), the conditions which explicate the extended rationality, one can infer that the ambivalence of the human place in creation forms the basis of the difference between theology and science, so that the very problem of relation and mediation between theology and science manifests the inevitability of this ambivalence in the core of the human condition.

\section{Self-affectivity of life as an inaugural saturated phenomenon and the ultimate foundation of the dialogue between science and theology}

The logic of our discussion brought us to the conclusion that the difference between science and theology can be qualified as a different philosophical reflection upon that which can be presented in phenomenality of objects on the one hand, and of the event-like phenomena whose phenomenality exceeds the boundaries of metaphysical definitions grounded in substantiality, causality, foreseeability, in the opposition of the possible and impossible. If such a distinction and difference of phenomenality were absolute no dialogue between science and theology would seem to be possible at all. This remains true in what concerns such singular events of communion as the Incarnation, Resurrection and Ascension, the hypostatic descent of the Holy Spirit on the apostles, etc. Despite the ongoing infinite historical, linguistic and theological hermeneutics of these events, they remain fundamentally irreducible to any sort of the worldly causality. However, in order for these events to be articulated rationally in response to their transcendent "appeal", one needs a receptible being, that is man. Generalising, one needs life which is "light to men". This life, proceeding from the Word, appears to man dualistically: 
one the one hand as life in the body in rubrics of space and time, when man is positioned as an object in terms of scales of the universe, and, on the other hand, as an inexpressible mystery of conscious existence from which the whole universe is articulated. Classical philosophy detected this ambivalence in the position of humanity by numerous ways and named it the "paradox of human subjectivity in the world". ${ }^{21}$ This paradox gives an example of the twofold interpretation of one and the same phenomenon of man: on the one hand, man appears in the phenomenality of objects as one physical object among the many; on the other hand, he is present as articulating consciousness in which the whole universe in totality of its space and time is brought to its recapitulation through the instant intellectual synthesis in the event of life of this consciousness. In other words, the phenomenality of man receives a different status depending on interpretation, that is on hermeneutics, thus showing that there is no phenomenal gulf between how he is presented in consciousness in the first and second case. One can speak of a variation in the modus of phenomenality as a consequence of the hermeneutic variation. A historical and philosophical pointer towards this link can be found in "Critique of Practical Reason" where Kant speculates as to how, in the case of man, to reconcile the seeming contradiction between human freedom and the mechanism of nature, to which man is subordinated because of his corporeal condition. He writes: "We must remember what was said in the 'Critique of Pure Reason', or what follows therefrom: that the necessity of nature, which cannot co-exist with the freedom of the subject, appertains only to the attributes of the thing that is subject to timeconditions, consequently only to those of the acting subject as a phenomenon... But the very same subject being on the other side conscious of himself as a thing in himself, ... regards himself as only determinable by laws which he gives himself through reason; and in this his existence nothing is antecedent to the determination of his will, .... the whole series of his existence as a sensible being, is in the consciousness of his supersensible existence nothing but the result ...of his causality as a noumenon" (Kant, 1959 [229]: 191). In other words, causality and other categories determine necessarily only the natural mechanism responsible for the actions of subjects as phenomena, but are not applicable to them as things in themselves. Moral freedom and natural necessity are harmonised in one and the same "object", that is man, by means of variation of the modus of phenomenality, the variation which became possible because of the hermeneutical variation in one and the same "object", that is man, as phenomenon and noumenon.

The entry of hermeneutics into the criterion of distinction between the modi of phenomenality (for example, between the phenomenality of objects (in science) and phenomenality of events (in theology)) points to that the difference in "view" of one and the same phenomenon originates in man, namely in variation of his intuition. For example, the transition from a perception of the universe as a physical spatiotemporal object to its contemplation as the event coincident with human life corresponds to the transition from the phenomenon of the universe with poor intuition to the universe as a saturated phenomenon with an excess of intuition. ${ }^{22}$ Then one can conjecture that the difference in interpretation of phenomena on the basis of scientific rationality and extended rationality of theology has its origin in man himself so that the difference between the scientific world-view and world's perception in the context of religious experience is linked to that intrinsic variability and flexibility of the human cognitive faculties from which this difference and possible forms of its explication (either conflict or consonance) 
arise. The paradox of human subjectivity in the world gives an example of ineluctable dichotomy in representation of the living experience of the world: namely its objective representation (man as a part of the universe) and its eventlike interpretation (when the whole universe is articulated in human consciousness). The mystery of this dichotomy (that is an ambivalent appearance of man to himself) remains and, being irrevocable in any knowledge of being, becomes a characteristic element of the human condition. Since, as we have discussed previously, one cannot produce a metaphysical "basis" for the phenomenon of man, the sense of the abovementioned dichotomy in perception of the human place in the universe remains also metaphysically inexplicable, so that the split in the scientific and theological perception of reality manifests the difference in the modi of phenomenality. The problem of relation between science and theology, seen in the perspective of history, sociology and even anthropology, becomes an inalienable characteristics of man and his unknowability by himself. One concludes then that any hope for establishing of such a dialogue between science and theology that could reconcile science and theology in a sort of unity, is existentially futile. ${ }^{23}$

Thus one needs to state that the major driving aspect of all discussions on science and theology is the incomprehensible facticity of man, his life and life as such. Both science and theology (together with philosophy) receive their ultimate foundation in events of life, originating from life as such. But since, in coherence with our previous argument, one cannot establish an ontological (metaphysical) foundation for the phenomenon of life, one cannot consider life on the same level with the rest of reality of nature, for life transcends the capacity of being presented in the phenomenality of objects by manifesting itself in the event of its sheer facticity as the possibility of all further phenomenalisations. The world thus becomes grasped and hence phenomenalised within the life-event horizon. The facticity of life and man that are treated theologically as the willing of the Word and the Spirit to create man in the image of the Holy Trinity (being de facto the givens of theology of communion), challenge philosophy by forcing it to develop the hermeneutics and phenomenology of that which is not apparent, that is of that which does not show itself, but is in the foundation of distinction between that which is alive (man) and which is not. Such a philosophy will have to rationally appropriate experience of communion as the faculty of thought and speech, following an ideal of freedom from slavery to nature and society, the unconditional acceptance of love as an ultimate principle of communion and being.

The invisible and indemonstrable phenomenon of life as such is explicated dramatically in the problem of man's birth, treated phenomenologically. By referring the reader to details on this subject elsewhere (Romano, 1998: 95-112), (Marion, 2003b: 87-105), (Marion, 2010: 291-99), we just would like to point out that the phenomenological inaccessibility to the event of birth as a hidden mystery of life in general, being implicitly present in all discussions on science and theology, explicates itself indirectly in both, historically and literary narrated events of Christian history, such a the Incarnation of the Word of God in Jesus Christ, as well as in scientific narrative of the beginning of the universe or of the inaugural event of the biological evolution. Then, since according to modern scientific world-view the whole physical world had its origin in the singular event in the past of the universe (the event whose contingent facticity is not elucidated by science itself), science ultimately appeals to the same intuition of "beginning" which pertains to the unknowability of man by himself, that 
unknowability which constitutes the initial and final point in the problem of science and theology. However, as in phenomenology of birth, where birth is not a point of "arrival" of life to somewhere, but a point of departure (for life to come into being it must arrive from life in general) the coming of the universe into being is not simply "birth" of the dead physical world from something that either logically or temporally preceded it, but rather represents the origin of a certain phenomenality of the world as a result of coming into existence of life. It is this that forms the beginning of theology understood not as "speculations of the human mind or a result of the critical study, but as a revelation of that being to which man was introduced by the operation of the Holy Spirit" (Sakharov, 1999: 171). It is the theology of the living presence of God rehabilitating the human subject, "sustaining him in his personal relations with God and with his fellow creatures" (Torrance, 1997b: 188). In theological activity as a modus of life "human reason finds itself posited with a given reality that is not a dumb or inert object of knowledge but the Holy Spirit speaking the Word of God and in that Word presenting the very Being of God as the creative source and objective ground of our knowledge of Him" (Torrance, 1997b: 182).

If thus the problem of origin of human life constitutes the core of the dialogue between theology and science, and this problem is theological by definition, it becomes clear that the relationship between science and theology cannot be "symmetric", so that the very positioning of the relationship as a relation "between" science and theology represents a misunderstanding. The very possibility of science as a consequence of facticity of life constitutes a theological problem, for one must first of all pose a question on the possibility of the scientific description of the world and its representation in the phenomenality of objects. This ultimately leads to a question of "the Giver of life" (as "the Giver of science"), that is to true theology as the willing of the Holy Spirit. Here theology again challenges philosophy by initiating in a rational response to such a gift of life new understanding of phenomenality of that (the "Giver of life") which is not transparent in rubrics of space and time.

The introduction of a pneumatological dimension into the discourse on science and theology must appear strange and irrelevant to scientists. If the reflection upon the logical structure of the world can at least touch upon the Christological problematic, for the Logos is present in the world in its intelligible laws and in consubstantiality between the universe as the body of the incarnate Christ, a reflection upon the Holy Spirit becomes much more problematic for the latter has never been present in the rubrics of space and time (apart from the event of Pentecost) despite the fact that He invisibly and inalienably was "present" behind the actualisation of the Incarnation in the physical world. It is because of this that it becomes a difficult task (even for theology) to detect the "presence" of the Spirit in the universe through his action upon history. The conceptual arrangement of theology thus needs philosophical methods dealing with the phenomenality of that which is not transparent, not shown, but that which implicitly present in the foundation of the very possibility of stating this non-transparency. One implies again a situation when the intuitive content of that which is not apparent exceeds the discursive capacity of its constitution, that is the encounter with the saturated phenomenon with the eventlike phenomenality. As it was expressed by T. Torrance, we encounter the Spirit "always as the Lord of implacable objectivity of His divine Being, objecting to our objectifying modes of thought and imparting Himself to 
us in accordance with the modes of His own self-revealing through the Word" (Torrance $1997[2]$, p. 173), that is by granting to us the proceeding from Him forms of His acquisition when true knowledge of things becomes knowledge not in the perspective of our nature, but from the disclosed self-affectivity of life as a pointer beyond its own limits. Paradoxically the Spirit points toward the impossibility of apprehending his presence in forms of thought and speech by exercising thus the possibility of grasping this impossibility. It is exactly this which places us under the constant bedazzling gaze of the Spirit that cannot be looked at. At the same time the vision of the sense of those realities which man encounters in the event-like experience of the Divine, is achieved through the actions of the Holy Spirit upon history referring thus the content of our thought and speech pertaining to events of communion beyond their space-time context. The Spirit is that action and operation of God with respect to us which makes our concepts and cognitive forms open to that which is not apparent, but that lies in the foundation of our capacity of detecting and apprehending the events of communion.

Scientific activity and articulation of the universe also have in their modi operandi the implicit presence of the "giver of life" so that the philosophical explication of scientific theories as originating in the event of life will make possible to shed light on the pneumatological dimension of science as such, as well as the pneumatological dimension of the relation between science and theology of communion.

\section{Instead of conclusion}

The immediacy of the given in theology of communion entails that this theology cannot acquire a metaphysical form thus demanding the extension of philosophy beyond metaphysics.
Philosophy has to incorporate into its scope the unobjectified phenomena and those aspects of human experience as birth, love to the other, the sensibility of one' own flesh as consubstantial to the universe, the perception of events etc. These saturated phenomena by evading the rubrics of metaphysical description slip away from any scientific interpretation. However if one needs to relate (hermeneutically) these phenomena to the scientific ones one must at least attempt to apprehend them philosophically. Here theology provides an example for philosophy: the extension of the latter is possible if one includes into its scope the givens of communion. Such an extension of philosophy implying the refusal of the transcendental stance in knowledge brings it to a purely empirical sphere, by disregarding an initial question on what can be know and what cannot. By being empirical because of its dependence on the transcendent, theology precedes philosophy in that sense that it formulates new challenges for philosophy in the conditions when the metaphysical and transcendental matrix of thinking can not be employed anymore. It is in this sense that one can talk of the rationality of theology in a more complicated and efficacious sense than in philosophy. The same can be said of theology in its "dialogue" (mediation) with special scientific disciplines when the latter ambitiously pretend to know the universe and man as if they are ontologically rooted in some primordial substance of the world. Here theology gently points out that there is the transcendent foundation of the contingent facticity of the human world whose presence is "sensed" as an incredible unknowability of the world but not in the sense of a lack of knowledge or time to apprehend it, but in the sense of excess making every mysterious and extraordinary instant of human life a "bedazzling event" of presence of light of the Life from the Word, the Word Who was with God and Who was God. 
1 We use the terminology of the "given" (instead of "data") in order from the beginning to underline the fact of presence of human subjectivity participation in detection, identification and articulation of phenomena in the form of "data". The "given" is not a dispassionate and neutral imposing of the world or God upon a human subject, but the "gift" granted to human being as a part of Being in general in order to comprehend existence.

2 (Heidegger, 1998a: 50). Com. with the test in Sein und Zeit, § 7, where Heidegger places theology on the same level with other disciplines dealing with the phenomena which are analysed by phenomenology (Heidegger, 1998b: 58).

3 On a non-trivial and ambiguous sense of the tem Ereignis in later Heidegger distinct from the modern hermeneutics of events see (Romano, 2010: 20-27).

4 See details on phenomenology of events in (Romano, 1998). A careful distinction of phenomenality of objects and phenomenality of events is discussed in (Marion, 2010: 243-308).

See in this context (Bitbol et al., 2009).

Maximus the Confessor, Cap. Theologicorum ET: (Palmer, 1986: 115).

Maximus the Confessor Various Texts on Theology (3.33), in (Pamer, 1986: 215).

Maximus the Confessor Various Texts on Theology (5.68), in (Palmer, 1986: 276).

Maximus the Confessor, Cap. Theologicorum 1.9. ET: (Palmer, 1986: 116).

See (Thunberg, 1995: 105).

Maximus the Confessor, Cap. de Charitate, 4.50. ET: (Palmer, 1986: 106).

12 The fact that human nature is unknowable follows from its being an image and likeness of God, that is that one Who is unknowable. A classical excerpt from patristic texts is that one of Gregory of Nyssa: "Since the nature of our mind, which is the likeness of the Creator, evades our knowledge, it has an accurate resemblance to the superior nature, figuring by its own unknowableness the incpomprehensible Nature" (Gregory of Nyssa, 1996: 397). See also an article (Marion, 2005: 1-24), as well as a chapter from (Marion, 2010: 21-86).

13 "Le monde est en suspens dans l'evenement; il s'origine depuis toujours pour nous dans des evenements. inauguraux, a commencer par celui - insigne - de la naissance" ("The world is hanging in the event; it always originates for us in inaugural events, beginning with the most privileged one - our birth") (Romano, 2010: 121).

14 See a detailed discussion of this statement in my book (Nesteruk, 2015: 73-81).

15 C. Yannaras describes "as "apophatic" that linguistic semantics and attitude to cognition which refuses to exhaust the content of knowledge in its formulation, which refuses to exhaust the reality of things signified in the logic of signifiers (Yannaras, 2004: 84). In philosophy, for example, it originates from an epistemological argument pertaining to a sort of linguistic reformulation of the Kantian transcendentalism (which is typical for post-structuralism) that language conditions the accessibility and intelligibility of reality. According to this view there is no access to the referent outside the linguistic effect, but the linguistic effect is no the same as that referent it attempts but fails to capture. This situation entails, in analogy with theology, a variety of ways of making such a reference, where none of which can claim it exclusiveness and true accessibility to what the reference is made. The range of cognitive situations which fall under the scope of apophaticism can be found in works of J.-L. Marion under the name of "saturated phenomenon" (see (Marion, 2001)). Theology on its side affirms that any knowledge of God if it pretends to be real and true cannot escape the conditions of incongruence between human knowing and the reality of God. This incongruence is the immanent feature of any serious theologising: one cannot raise questions on the reality of God from some position which excludes a particular feature of the Divine manifestation which is included in the very irreducibility of any speech about God to that reality which is predicated through this speech. See, for example, (Torrance, 1997: 52-55).

16 Clement of Alexandria, Stromaties 1.2, in A. Roberts and J. Donaldson (eds.), The Ante-Nicene Fathers, vol. 2, (Grand Rapids, MI: W.B. Eerdman Publishing Company, 1962).

17 Stromaties 2.4

18 Augustine of Hippo, Civitate Dei, VIII, 1. ET: (Betteson, 1980: 298).

19 St. Augustine (1994). Contra Faustum, Book 32, 18. ET: The Nicene and Post-Nicene Fathers, ed. P. Schaff and H. Wace, Ser. 1, vol. 4 (Grand Rapids, MI: W. B. Eerdman Publishing Company), p. 581.

20 St. Augustine (2003). De Trinitate, 12, XI (16). ET: On the Trinity, ed. G.E. Matthews (Cambridge: Cambridge University Press), p. 94.

21 См. (Carr, 1999), (Nesteruk, 2015: 135-153).

22 Les phénomènes saturés - the so called "saturated phenomena" stand for the group of phenomena which cannot be represented in the phenomenality of objects, that is in rubrics of quantity, quality, relation and modality. The issue is that certain phenomena do not manifest themselves in the mode of objects and yet still do manifest themselves. These phenomena undergo saturation by the excess of intuition over the concept or signification in them. Correspondingly the saturated phenomena cannot be constituted because they are saturated. Experience of the saturated phenomena cannot be predetermined by a transcendental subject: it is to the extent that ego cannot comprehend the phenomenon that this ego is constituted by it. The examples of the saturated phenomena can be found in various fields of the human activity: painting, revelation of the Divine, the givenness of truth, events of life, experience of flesh, the erotic phenomenon etc. Theory of the saturated phenomena was advanced in (Marion, 2001) and (Marion, 2003).

23 One can quote S. Frank who made a comment that any attempt to remove this dichotomy in man or explain it away by means a materialistic regress in thinking leads ineluctably to the distorted anthropology and hence cosmology: man has a "dual nature, and every theory of life which fails to account of both aspects of his being is bound to be inadequate... The structure of our being is complex and antinomic, and all artificial simplification distorts it" (Frank, 1966: 34-35). 


\section{Reference}

Augustine (1980). Civitate Dei. ET: H. Betteson, Augustine. Concerning the City of God against Pagans, New York: Penguin Books.

Augustine (1994). Contra Faustum. ET: The Nicene and Post-Nicene Fathers, ed. P. Schaff and H. Wace (Grand Rapids, MI: W.B. Eerdman Publishing Company). Ser. 1, vol. 4.

Augustine (2003). De Trinitate, 12, XI (16). ET: On the Trinity, ed. G.E. Matthews. Cambridge: Cambridge University Press. P. 94.

Bitbol, M., Kerszberg, P., Petitot, J. (eds.) (2009), Constituting Objectivity. Transcendental Perspectives on Modern Physics. Springer.

Carr, D. (1999). Paradox of Subjectivity. Oxford: Oxford University Press.

Clement of Alexandria (1962). Stromaties. ET: in A. Roberts and J. Donaldson (eds.), The AnteNicene Fathers, vol. 2. Grand Rapids, MI: W.B. Eerdman Publishing Company.

Frank, S. (1966). Reality and Man. New York: Taplinger.

Gregory of Nyssa (1996). De hominis opificio. ET: On the Making of Man in The Nicene and PostNicene Fathers, ed. P. Schaff and H. Wace. Grand Rapids, MI: W.B. Eerdman Publishing Company, vol. 5, 387-427.

Heidegger, M. (1998a). "Phenomenology and Theology", in Pathmarks, ed. William McNeill. Cambridge: Cambridge University Press, 39-62.

Heidegger, M. (1998b). Being and Time. Oxford: Blackwell.

Heidegger, M. (1972). “Time and Being”, in On Time and Being. New York: Harper \& Row Publ, $1-24$.

Kant, I. (1959). Critique of Practical Reason, tr. T.K. Abbott. London: Longmans.

Marion, J.-L. (2001). Du sucroît. Etudes sur les phénomenes saturés. Paris: Presses Universitaires de France.

Marion, J.-L. (2003a). Le phénomène érotique. Paris: Grasset.

Marion, J.-L. (2003b). "The Event, the Phenomenon and the Revealed", in Transcendence in Philosophy and Religion, ed. J.F. Faulconer. Bloomington and Indianapolis: Indiana University Press, 87-105.

Marion, J.-L. (2005). "Mihi magna quaestio factus sum: The Priviledge of Unknowing", In The Journal of Religion 85, 1, 1-24.

Marion, J.-L. (2010). Certitudes negatives. Paris: Bernard Grasset.

Maximus the Confessor. Cap. Theologicorum. ET: Two Hundred Texts on Theology and the Incarnate Dispensation of the Son of God, in Palmer et al, The Philokalia, 2, 114-63.

Maximus the Confessor. Various Texts on Theology, in Palmer et al, The Philokalia, 2, 164-284.

Maximus the Confessor. Cap. de Charitate. ET: Four Hundred Texts on Love, in Palmer et al., The Philokalia, 2, 53-113.

Nesteruk, A. (2015). The Sense of the Universe. Philosophical Explication of Theological Commitment in Modern Cosmology. Minneapolis: Fortress Press.

Palmer, G.E.H., Sherrard, Ph., and Ware, K. (1986). The Philokalia: St. Nikodimos of the Holy Mountain and St. Makarios of Corinth. The Philokalia: The Complete Text, vol. 2, ed. London: Faber.

Pascal, B. (2001). De l'art de persuader. Paris: Éditions mille et une nuits.

Pascal, B. (1962). Pensées. Tr. Louis Lafuma. Paris: Éditions du Seul. 
Romano, C. (1998). L'événement et le monde. Paris: Presses Universitaires de France.

Romano, C. (2010). L'aventure temporelle. Trois essais pour introduire à l'herméneutique événemential. Paris: Presses Universitaires de France.

Sakharov, Sophrony (Archimandritre) (1999). St. Silouan the Athonite. Moscow: St. Trinity and Sergius Lavra.

Thunberg, L. (1995). Microcosm and Mediator. The Theological Anthropology of Maximus the Confessor. Chicago: Open Court.

Torrance, T.F. (1997a). Space, Time and Incarnation. Edinburgh: T\&T Clark.

Torrance, T.F. (1997b). God and Rationality Edinburgh: T\&T Clark.

Yannaras, C. (2004). Postmodern Metaphysics. Brookline, MS: Holy Cross Orthodox Press.

\title{
Философские основания диалога между наукой и богословием
}

\author{
А.В. Нестерук \\ Университет Портсмута \\ Англия, POІ ЗНF, Портсмут, корпус Лайон Гэйт
}

\begin{abstract}
В статье обсуждаются философские трудности осуществления диалога между наукой и богословием. Богословие имеет дело с явлениями типа событий, к которым неприменимы критерии метафизики и онтологии. Таким образом, философия, осуществляющая посредничество между наукой и богословием, вынуждена включать в свой объем необъективируемые феномены, как рождение человека, любовь другого, ощущение своей плоти как единосущной всей вселенной, переживание событий Библейской истории и др. Расширение философии возможно, если включить в состав ее данного содержание опыта богообщения, опосредованного эпистемологическими критериями расширенной «раџиональности», исходящей из абсолютного приоритета загадочности человека, его сознания и жизни вообще. Такое расширение философии, предполагающее отказ от трансиендентальной установки, выводит ее в принципиально эмпирическую сферу, отбрасывая в сторону исходный вопрос о том, что может быть исследовано, а что нет. Различие между научным опытом и опытом религиозным в философских терминах показывает, что это различие является базовой характеристикой человеческого состояния, и его преодоление под видом «диалога» является экзистенциально несостоятельным предприятием. Обсуждения различия в опыте мира и опыте Бога необходимы для дальнейшей артикулящии смысла человеческого состояния, но не его изменения.
\end{abstract}

Ключевые слова: антропология, богословие, герменевтика, жизнь, наука, опыт, событие, сопричастие, феноменальность, философия, человек.

Научная специальность: 09.00.00 - философские науки. 